\title{
ИНТЕГРАЦИЯ ИЗОБРАЗИТЕЛЬНОГО ИСКУССТВА И ХУДОЖЕСТВЕННОЙ ФОТОГРАФИИ КАК ФАКТОР ПОВЫШЕНИЯ МОТИВАЦИИ МЛАДШИХ ШКОЛЬНИКОВ В СИСТЕМЕ ДОПОЛНИТЕЛЬНОГО ОБРАЗОВАНИЯ
}

\begin{abstract}
Марущенко Маргарита Николаевна
студент 3-го курса магистратуры факультет дошкольного, начального и специального образования педагогического института (Изобразительное искусство) Научный руководитель: Даниленко Анжела Павловна к.п.н., доцент ФГАОУ ВО «Белгородский государственный национальный исследовательский университет» (НИУ «БелГУ»)
\end{abstract}

\begin{abstract}
Аннотация: В статье рассмотрены возможности интеграции изобразительного искусства и художественной фотографии на занятиях художественно - творческой деятельности в системе дополнительного образования. Представлены методические аргументы повышения мотивации и интереса младших школьников посредством интеграции изобразительного искусства и художественной фотографии.
\end{abstract}

Ключевые слова: мотивация, творческие способности, дополнительное образование, интеграция, изобразительное искусство, художественная фотография, художественно - творческая деятельность.

\section{INTEGRATION OF VISUAL ART AND ARTISTIC PHOTOGRAPHY AS A FACTOR OF INCREASING THE MOTIVATION OF YOUNGER SCHOOLCHILDREN IN THE SYSTEM OF ADDITIONAL EDUCATION}

\section{Marushchenko Margarita Nikolaevna Danilenko Angela Pavlovna}

\begin{abstract}
The article considers the possibilities of integrating fine art and artistic photography in the classes of artistic and creative activity in the system of additional education. Methodological arguments for increasing the motivation and
\end{abstract}




\section{СОВРЕМЕННЫЕ ТЕХНОЛОГИИ:

interest of younger schoolchildren through the integration of fine art and artistic photography are presented.

Key words: motivation, creativity, additional education, integration, fine art, artistic photography, artistic and creative activity.

Глубокие перемены, происходящие в нашем современном обществе, обуславливают потребность в активной, творчески развитой личности, умеющей грамотно использовать свои творческие возможности в художественно-творческой деятельности, а в дальнейшем и в будущей профессии, и в жизни. Активно идет формирование личности школьника.

Особо действенными в формировании творческой личности является различные виды искусства. Дополнением к школьному образованию идет и сформированная система дополнительного образования, которая развивает, формирует, даёт возможность школьнику развить на наиболее высоком уровне и реализовать свои творческие потребности.

Одной из центральных проблем современного образования можно назвать формирование учебной мотивации и интереса у младших школьников. И в этом помогает дополнительное образование, которое воспитывает и развивает навыки, умения в художественно - творческой деятельности.

Мы знаем, как велико значение изобразительного искусства в системе развития личности и воспитании ребенка. Занятия различными видами художественного творчества особенно действенно влияет на развитие личности. И в этом помогают межпредметные связи, которые отражают комплексный подход к воспитанию и обучению. И мы знаем, как велико значение изобразительного искусства в системе развития и воспитания личности.

Искусство художественной фотографии как один из видов художественного творчества особенно действенно активизирует интерес к художественно-творческой деятельности. Но если добавить к изучению художественного творчества - изучение процесса создания фотографий, знакомство с секретами художественной фотографии, то развитие личности становится богаче и интереснее.

«Теоретическое обоснование и разработка основных принципов межпредметной интеграции (изобразительное искусство и художественная фотография) в рамках развивающего обучения в системе дополнительного 


\section{СОВРЕМЕННЫЕ ТЕХНОЛОГИИ:

образования является фактором повышения учебной мотивации и интереса младших школьников. Теоретическая значимость заключается в разработке основных компонентов обучения младших школьников в системе дополнительного образования, реализующей межпредметную интеграцию».

Практическая значимость повышение учебной мотивации и интереса у младших школьников на занятиях художественно-творческой деятельностью, заинтересованность учебным процессом и его результатом» [6, с. 134].

Необходимо осуществлять поиск новых эффективных путей формирования и повышения учебной мотивации у младших школьников на занятиях художественно-творческой деятельностью (на примере художественной фотографии).

Интеграция может осуществляться среди таких учебных предметов, как изобразительное искусство и художественная фотография. В этом направлении нам помогает разработанная авторская дополнительная программа художественной направленности «Фотохудожник» для учащихся 1-11 классов с применением фотографических технологий и средствами художественной фотографии на занятиях художественно-творческой деятельностью в системе дополнительного образования.

В рамках интеграции изобразительного искусства и художественной фотографии педагог может заранее определить, что считать важным, а что второстепенным, чтобы научить своих учеников применять педагог свои творческие умения, навыки на практике, основываясь на полученных знаниях. Тем самым решается важная задача современного образования - умение грамотно использовать свои знания, умения, навыки в практической художественной деятельности на занятиях в системе дополнительного образования.

Чтобы образование считалось качественным, необходимо уделять пристальное внимание занятиям художественно-творческой деятельностью начального звена, а именно формированию познавательных интересов как фактору мотивации младших школьников. Необходимо отметить, что формировать и развивать навыки, повышая интерес к обучению в возрастной период от 7 до 11 лет. Именно в этот период нужно давать учащимся базовые знания, умения. Формировать и развивать навыки, чтобы ребенок учился рисовать. Методика обучения с использованием методики преподавания искусства фотографий на занятиях художественно-творческой деятельности 


\section{СОВРЕМЕННЫЕ ТЕХНОЛОГИИ:

в системе дополнительного образования даёт положительный результат знания, умения, навыки, их уровень повышается, а значит происходит положительное движение в сторону мотивации при изучении изобразительного искусства и художественной фотографии. В этот период необходимо окружить ребёнка такой средой и такой системой отношений, которые стимулировали бы самую разнообразную творческую деятельность и способствовали эффективному развитию творческих способностей.

На данном этапе необходимо уделять внимание методике преподавания, а именно «организационному моменту на занятиях».

«Организационный момент урока является важным этапом в процессе формирования познавательного интереса у учащихся. В разное время года для его обозначения применялись такие термины, как «интригующее начало урока», «эмоциональная завязка урока», «активизация внимания» и др. Но как показывает школьная практика, обычно этот этап проходит спонтанно, не используются все его возможности», - пишет Ушакова М.А [7].

Вероятно, все дело в том, что нет конкретных методических рекомендаций для проведения организационного момента урока.

«Оргмомент обязательно должен мотивировать детей на достижение поставленных целей. Можно актуализировать мотивы предыдущих достижений («Мы хорошо поработали над предыдущий»), вызывать мотивы относительной неудовлетворенности («Но не усвоили еще важную сторону этой темы»), усиливать мотивы ориентации на предстоящую деятельность («А, между тем, это будет необходимо»), усиливать непроизвольные мотивы удивления, любознательности.

Необходимо опираться на собственный опыт учителя и его индивидуальные особенности, тогда можно продумать свое сочетание приемов мотивации, учитывая возможности школьников» [6].

На занятиях художественно - творческой деятельности в системе дополнительного образования применяются фотографические технологии, изучаются правила создания фотографий, правила по созданию композиции. Но прежде чем приступить к изучению тем по художественной фотографии, необходимо настроить младших школьников к готовности выполнять творческие задания - создание рисунков. И вот в этот момент педагог активизирует познавательную деятельность учащихся через необычное начало урока, мобилизирует внимание учащихся. Для решения этой задачи педагог 


\section{СОВРЕМЕННЫЕ ТЕХНОЛОГИИ:

предлагает использовать «активные методы и приёмы обучения»: рифмованное начало урока, пословицы, поговорки, относящиеся к теме урока, постановка проблемного вопроса.

Дополнительная общеразвивающая программа художественной направленности «Фотохудожник» рассчитана на 2 года обучения. На протяжении всего этапа обучения применяются разные методы обучения, такие как: объяснительно-иллюстративный; методы преподавания (рассказ, беседа, объяснение и др.); творческий; частично - поисковый; проблемного изложения; методы, обеспечивающие самовыражение обучающихся, эвристические, репродуктивные. Учащиеся создают фотографии по теме: «Съёмка пейзажей», «Законы композиции в фотографии», а затем создают рисунки с составлением композиции рисунка, передают красками настроения. Выполнение задания: «Сельский пейзаж», «Зимний пейзаж», «Городской пейзаж».

Использование фотографий на занятиях художественно-творческой деятельности в качестве иллюстраций, учащиеся имеют возможность сравнивать такие виды искусства, как изобразительное искусство и художественная фотография. Например, при изучении темы «Пейзаж» учащиеся сначала знакомятся с видами пейзажа в изобразительном искусстве, потом - видами пейзажа на занятиях художественной фотографии. Учащиеся учатся анализировать фотографии, изучают законы перспективы в изобразительном искусстве и на занятиях художественной фотографии. Знакомятся с правилами построения композиции в двух данных направлениях, создают рисунки, учитывая правила создания перспективы на листе бумаги и при создании фотографий. При анализе рисунков узнают, что перспектива изображается в серых, голубых, фиолетовых тонах, нет четкости изображения. А затем, рассматривая и анализируя вместе с педагогом художественные фотографии, отмечают, что, например, дальний план на художественной фотографии показан четко: видны деревья, веточки, листики. От чего это зависит? Объектив, его функции дают возможность увидеть картину четко. Делается акцент на изображение дальнего плана на рисунке и на фотографии. Изображение дальнего плана на рисунке и на фотографиях разное. В дальнейшем, учащиеся при работе с перспективой при изучении изобразительного искусства правильно изображают дальний план (размыт, цвета: серый, голубой, фиолетовый). 


\section{СОВРЕМЕННЫЕ ТЕХНОЛОГИИ:

А при создании фотографий, учитывают правила их создания («золотое сечение», «уравновешенность кадра» и т.д.)

Таким образом, учащиеся, изучая одновременно такие виды искусства, как изобразительное и художественная фотография, повышают свои практические и теоретические навыки, умения, тем самым происходит развитие творческих способностей, повышается мотивация и интерес к художественно-творческой деятельности и к художественной фотографии.

Соединение и изучение фотографического искусства и изобразительной деятельности на занятиях дополнительного образования приводит к приобретению определенных системных понятий и практических навыков и умений в данных областях, учащиеся получают возможность удовлетворить потребность в созидании, реализовать желание создавать нечто новое своими силами и в области фотографии, и в области изобразительного искусства.

\section{Список литературы}

1. Беда Г.В. Основы изобразительной грамоты: Рисунок, живопись, композиция. 2-е изд. перераб. и доп. М.: Просвещение, 1981. - 239 с.

2. Борев Ю.Б. Эстетика: Учебник. - М.: Высш. шк., 2002 - 511 с.

3. Брюс Бэрнбаум. Сущность фотографии. Умение видеть и творить. / Брюс Бэрнбаум. Изд. - Питер, 2016. - 176 с.: ил.

4. Ильин Е.П. Мотивация и мотивы. - СПб.: Питер, 2000.- 512 с.

5. Марущенко М.Н., Даниленко А.П. Проектно-исследовательская деятельность художественной направленности как средство развития творческого потенциала у одарённых детей / Художественно-графический факультет: история и современность: материалы Всероссийской научно-практической конференции, посвящённой 60-летнему юбилею художественно-графического факультета Орловского университета. г. Орел: ОГУ имени И.С. Тургенева, 2020 г. -307 с.

6. Семенова И.А. Организационный момент урока /Статья. [Электронный ресурс] / Семёнова И.А. // Режим доступа: https://videouroki.net/ razrabotki/orghanizatsionnyi-momient-uroka.html.

7. Ушакова М.А. Формирование интеллектуально - творческих умений младших школьников в процессе учебной деятельности. Статья. [Электронный pecypc] / Ушакова М.A. // Режим доступа: режим доступа: https:// cyberleninka.ru/article/n/formirovanie-intellektualno-tvorcheskih-umeniy-mladshihshkolnikov-v-protsesse-uchebnoy-deyatelnosti/viewer. 